\title{
Thrombospondin-1 at the crossroads of corpus luteum fate decisions
}

\author{
Svetlana Farberov, Raghavendra Basavaraja and Rina Meidan \\ Department of Animal Sciences, The Robert H. Smith Faculty of Agriculture, Food and Environment, The Hebrew \\ University of Jerusalem, Rehovot, Israel
}

Correspondence should be addressed to R Meidan; Email: rina.meidan@mail.huji.ac.il

\begin{abstract}
The multimodular matricellular protein thrombospondin-1 (THBS1) was among the first identified endogenous antiangiogenic molecules. Recent studies have shown THBS1-mediated suppression of angiogenesis and other critical activities for corpus luteum (CL) regression. THBS1 is specifically induced by prostaglandin F2alpha in mature $\mathrm{CL}$ undergoing regression, whereas luteinizing signals such as luteinizing hormone and insulin reduced its expression. THBS1 interacts both synergistically and antagonistically with other essential luteal factors, such as fibroblast growth factor 2, transforming growth factor beta1 and serpin family E member 1, to promote vascular instability, apoptosis and matrix remodeling during luteal regression. Expression of THBS1 is also downregulated by pregnancy recognition signals to maintain the $\mathrm{CL}$ during early pregnancy. This dynamic pattern of luteal expression, the extensive interactivity with other luteal factors and strong antiangiogenic and proapoptotic activities indicate that THBS1 is a major determinant of CL fate.

Reproduction (2019) 157 R73-R83
\end{abstract}

\section{Introduction}

The corpus luteum $(\mathrm{CL})$ is a transient endocrine gland that develops from the preovulatory follicle after ovulation. A functional $\mathrm{CL}$ is critical for successful mammalian reproduction. Extension of luteal lifespan and secretion of progesterone are required for establishing and maintaining pregnancy. Conversely, regression of the $\mathrm{CL}$ in the absence of a viable embryo is necessary for the initiation of a new reproductive cycle. The $\mathrm{CL}$ lifespan is characterized by rapid growth, differentiation and controlled regression, phases accompanied by intense angiogenesis, stabilization and angioregression, respectively (Niswender et al. 2000, Schams \& Berisha 2004, Shirasuna et al. 2012). Prostaglandin F2alpha (PGF2a) is the principal luteolytic hormone in cattle and many other species with an estrous cycle. It is secreted by the uterus in a non-fertile cycle (McCracken et al. 1999, Niswender et al. 2000). Endogenous PGF2a or its exogenous administration initiates a cascade of events leading to the irreversible demise of the CL. During this process, the $\mathrm{CL}$ undergoes dramatic changes in its steroidogenic capacity, vascularization, extracellular matrix (ECM) remodeling and cell viability (Schams \& Berisha 2004, Miyamoto et al. 2010, Meidan et al. 2017). An intriguing question concerning bovine luteal function is its refractoriness to the luteolytic actions of PGF2a in the early luteal phase, which lasts up to day 5 of the bovine estrous cycle (Lauderdale 2009).
To obtain a better understanding of early $\mathrm{CL}$ resistance to PGF2a-induced luteolysis, Mondal et al. compared the transcriptome of PGF2a-responsive bovine $\mathrm{CL}$ on day 11 of the estrous cycle to that of PGF2a-refractory $\mathrm{CL}$ on day 4 , both before and at two time points ( 4 and $24 \mathrm{~h}$ ) after PGF2a administration (Mondal et al. 2011). This study revealed a potential functional relationship between angiogenesis and the luteolytic response to PGF2a. PGF2a markedly increased expression of the proangiogenic factor fibroblast growth factor 2 (FGF2) in the PGF2a-refractory (day 4) CL. In contrast, antiangiogenic genes were specifically and highly induced in the PGF2a-responsive (day 11) CL. These antiangiogenic genes included thrombospondin 1 and 2 (THBS1 and 2), transforming growth factor beta 1 (TGFB 1) and serpin family E member 1 (SERPINE1) (Mondal et al. 2011, Berisha et al. 2016, Farberov \& Meidan 2016). The present review summarizes current knowledge on the regulation of THBS1 expression and its role in cell survival and blood vessel dynamics within the $\mathrm{CL}$.

\section{The thrombospondin family}

The thrombospondins are a family of five conserved extracellular multidomain glycoproteins. Members of this family play essential roles in regulating cell-cell and cell-matrix interactions (Bornstein 2001). These proteins can be subdivided into two structural groups: subgroup 
A comprising THBS1 and THBS2, which have the same set of structural domains and subgroup B comprising THBS3-THBS5, which are shorter and lack both regions related to procollagen type I repeats and the fourth type II repeat (Adams \& Lawler 2011).

THBS1 and THBS2 were among the first endogenous protein inhibitors of angiogenesis to be identified (Bornstein 2009). Knockout mice show increased vascularization (Lawler et al. 2001, Wang et al. 2003), suggesting that THBS1 inhibits angiogenesis. Although THBS1 and THBS2 are structurally similar, they differ in their expression patterns, localization and some functions (Lawler 2000, Bornstein 2001, Adams \& Lawler 2004). Indeed, THBS1- and THBS2-knockout mice have distinct phenotypes (Adams \& Lawler 1993, Kyriakides et al. 1998, Lawler et al. 1998).

THBS1 is a $420 \mathrm{kDa}$ homotrimer; each monomer consists of an $\mathrm{N}$-terminal globular module followed by a coiled-coil oligomerization domain, a procollagen module, three properdin-like type I repeats (TSR1), epidermal growth factor (EGF)-like type II repeats (TSR2), type III repeats (TSR3) and a C-terminal globular domain (Carlson et al. 2008).

Each domain of THBS1 interacts specifically with different molecules. The $\mathrm{N}$-terminal domain interacts with low-density lipoprotein receptor-related protein (LRP1), heparin sulfate proteoglycans (HSPGs) and a number of integrins (Tan et al. 2006). Adjacent to the $\mathrm{N}$-terminal, there is a region that is homologous to procollagen. This domain is involved in the assembly of the protein into a trimer (Sottile et al. 1991). All five members of the THBS family have the repeat domain types II and III, but only THBS1 and THBS2 contain the type I repeats. The type I repeat region is the most studied antiangiogenic epitope of THBS1 as it mediates interactions with the CD36 receptor, fibronectin, HSPGs and latent TGFB1 (Jimenez et al. 2000, Murphy-Ullrich \& Poczatek 2000, Resovi et al. 2014). The type II repeats mediate cell adhesion by binding beta 1 integrins (Calzada et al. 2004). The type III repeats contain the integrin recognition motif RGD (Kvansakul et al. 2004) and a binding site for FGF2 (Colombo et al. 2010). This binding site inhibits angiogenesis by sequestration of FGF2 (Colombo et al. 2010, Pagano et al. 2012). The COOH-terminal domain of THBS1 binds CD47, also known as an integrin-associated protein (Brown \& Frazier 2001). Therefore, owing to its structural and functional domains, THBS1 can simultaneously bind to cell-surface receptors, ECM components, proteolytic enzymes, cytokines and growth factors.

\section{Hormonal regulation and expression patterns of thrombospondins in the ovary}

THBS1, THBS2, and their receptors (CD36 and CD47) are widely expressed in the ovary, including granulosa cells (GCs), luteal steroidogenic cells and endothelial cells (ECs) (Dreyfus et al. 1992, Higuchi et al. 1999, Petrik et al. 2002, Zalman et al. 2012, Farberov \& Meidan 2014, Berisha et al. 2016). Studies in rat, bovine, marmoset and human have confirmed that within the follicle, THBSs are primarily produced in the GC layer (Dreyfus et al. 1992, Higuchi et al. 1999, Petrik et al. 2002, Greenaway et al. 2005, Thomas et al. 2008). Upon differentiation by FSH and forskolin, the ability of GCs to produce and bind THBS1 is inhibited (Dreyfus et al. 1992). In agreement, a recent study reported that in vitro luteinization by $\mathrm{LH}$ plus insulin reduced expression levels of THBS1, THBS2 and CD36 in bovine GCs (Fig. 1) (Farberov \& Meidan 2014). However, studies in rodents reported increased expression of Thbs 1 and Thbs2 in developing CL immediately after ovulation (Bagavandoss et al. 1998, Petrik et al. 2002). A possible explanation for this seeming paradox of high THBS expression in a period of rapid vascular growth is that this increase is not hormone induced but rather due

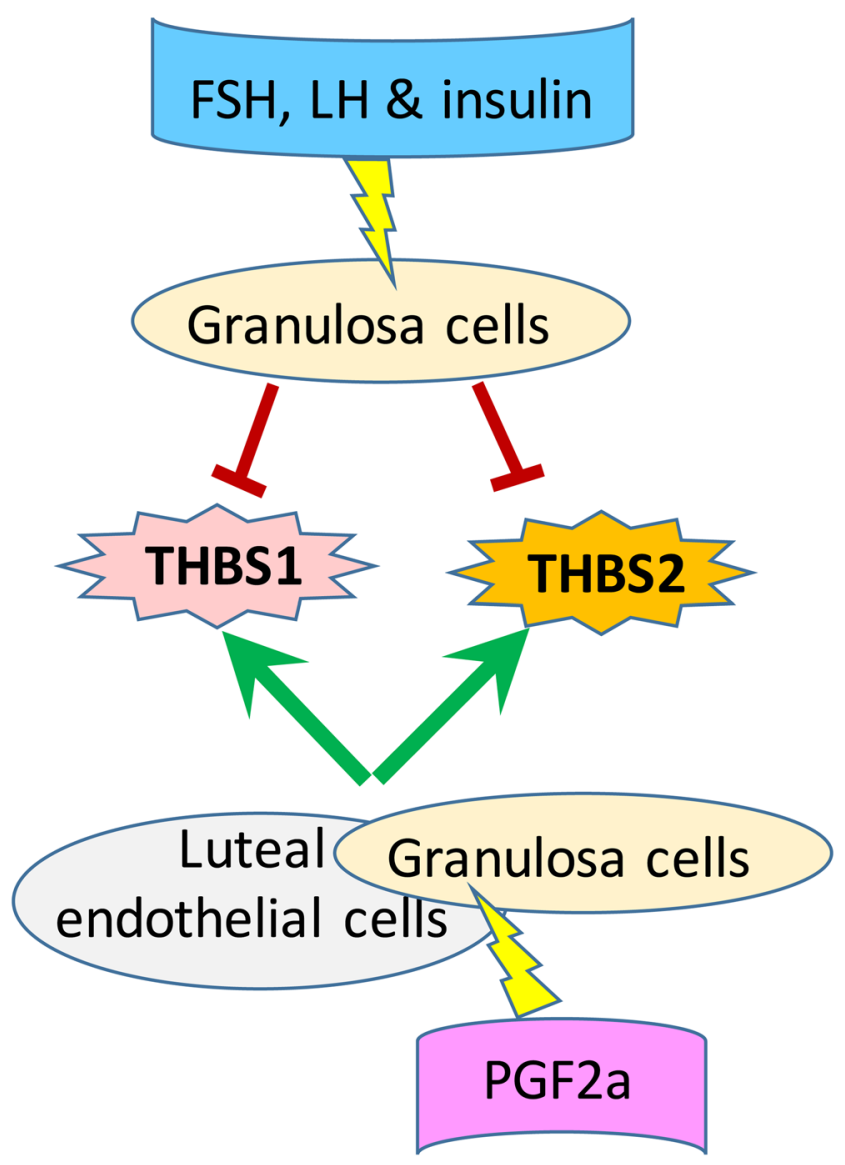

Figure 1 Hormonal regulation of thrombospondin (THBS) expression in ovarian cells. Follicular maturation induced by follicle-stimulating hormone (FSH) and luteinization stimulated by luteinizing hormone (LH) and insulin decrease expression of THBS1 and THBS2 in bovine granulosa cells (GCs). Treatment with prostaglandin F2alpha (PGF2a treatment) on the other hand elevates the expression of THBS1 and THBS2 in both luteal ECs and GCs. 
to a massive migration of ECs into the central region of the developing $\mathrm{CL}$. This contention is supported by THBS1 immunostaining in the forming CL (days 1-2) showing weak THBS1 expression in large luteal cells and strong expression in capillary ECs (Berisha et al. 2016). THBS1, THBS2, CD36 and CD47 are colocalized in follicles, suggesting that THBS ligands and receptors may contribute to the autocrine control of follicular cell function (Higuchi et al. 1999, Petrik et al. 2002, Greenaway et al. 2005, Berisha et al. 2016).

In the CL, THBSs and their receptors exhibit cellspecific expression. THBS1 is the predominant form expressed in luteal ECs during early and midluteal stages (Zalman et al. 2012, Berisha et al. 2016), whereas THBS2 is the major form in luteinized granulosa cells (LGCs) (Farberov \& Meidan 2014). CD36 expression was found only in LGCs, whereas CD47 expression did not display an appreciable difference in the expression level between these two cells types (Farberov \& Meidan 2014).

THBSs and their receptors are dynamically expressed across the luteal lifespan in cow and sheep ovary (Zalman et al. 2012, Romero et al. 2013, Berisha et al. 2016). Berisha et al. (2016) found that mRNA expression levels of THBS1, THBS2 and CD47 in the CL were high and relatively stable during the estrous cycle, whereas CD36 expression precipitously increased in the regressing $\mathrm{CL}$. In general, the ability of the bovine $\mathrm{CL}$ to undergo PGF2a-induced luteolysis is correlated with the upregulation of THBS1, THBS2 and CD36 (Zalman et al. 2012, Berisha et al. 2016, Farberov \& Meidan 2016). Notably, PGF2a treatment in vitro upregulated THBS1 and THBS2 expression in both luteal ECs and LGCs (Fig. 1) (Zalman et al. 2012). Likewise, CD47 displayed a significant and persistent increase in the mature (day 11) CL at 4 and $24 \mathrm{~h}$ after PGF2a administration (2.2fold relative to the 0 time point) (Farberov \& Meidan, unpublished data). The expression of CD47 was also induced in cultured LGCs by PGF2a treatment (Farberov \& Meidan 2014). In contrast to cyclic CL, expression levels of THBSs and receptors were downregulated for the whole duration of pregnancy (Berisha et al. 2016). Furthermore, studies in ewes showed an increase in THBS1 mRNA in regressing CL that was inhibited by early pregnancy (Romero et al. 2013). Interferon tau (IFNt), a maternal pregnancy recognition factor secreted during early pregnancy by the conceptus, exerts endocrine actions in the CL (Bott et al. 2010, Romero et al. 2015, Basavaraja et al. 2017). It was recently reported that the expression of THBS1 was downregulated in bovine $\mathrm{CL}$ slices and cultured luteal ECs incubated with IFNt (Basavaraja et al. 2017). The same study also found that IFNt reduced TGFB1 and SERPINE1, which are interconnected with THBS1, during luteolysis (Farberov \& Meidan 2016, Meidan et al. 2017). Inhibition of the THBS1-TGFB1-SEPRINE1 feed-forward process may be critical for maintaining the $\mathrm{CL}$ during early pregnancy.
The temporal expression and localization patterns of THBSs and their receptors during follicular maturation and across luteal lifespan are compatible with inhibitory functions in ovarian angiogenesis.

\section{THBS1 promotes apoptosis of ovarian cells}

The induction of apoptosis by THBS1 is essential for its antiangiogenic activity (Jimenez et al. 2000). THBS1 was found to inhibit angiogenesis in whole rat follicles in vitro and to directly induce apoptosis of GCs in vitro (Garside et al. 2010a). A study in marmoset monkeys showed that in vivo treatment with ABT-898 (a mimetic peptide of THBS1 type I repeats (Garside et al. $2010 b)$ ) reduced endothelial cell proliferation in the thecal layer of preantral and early antral follicles and suppressed GCs proliferation in developing follicles. This treatment also increased the incidence of atresia in preantral and early antral follicles (Garside et al. 2010b). The expression levels of THBSs and associated receptors decrease as follicular development progresses (Petrik et al. 2002, Greenaway et al. 2005, Thomas et al. 2008, Berisha et al. 2016), while THBS1 is upregulated during atresia (Thomas et al. 2008).

Recent studies in bovine luteal cells have utilized RNA interference to show that THBS1 compromises the viability of both luteal ECs and LGCs (Farberov \& Meidan 2014). Studies using a siRNA to downregulate endogenous THBS1 expression have providing evidence for a local proapoptotic effect of THBS1 in luteal cells. Cleaved caspase-3 levels were significantly reduced in THBS1-silenced luteal ECs as well as LGCs. Furthermore, silencing of THBS1 in luteal ECs rendered these cells more competent to withstand cell death induced by exposure to staurosporine (Farberov \& Meidan 2014). These findings suggest that endogenous THBS1 acts as a proapoptotic compound in luteal cells. It is widely accepted that apoptosis occurs during structural luteolysis (Juengel et al. 1993, Rueda et al. 1999, Yadav et al. 2005), and these findings strongly suggest that THBS1 is essential for the apoptotic demise of the CL.

Several studies have reported that the antiangiogenic effects of THBS1 are mediated, at least partially, by the CD36 receptor. Indeed, CD36 activation triggers a signaling cascade leading to endothelial cell death by apoptosis and the collapse of tumor vessels (Jimenez et al. 2000, Nicholson et al. 2001, Simantov et al. 2005). However, among the various bovine luteal cells, this receptor was found to be expressed mainly in LGCs (Farberov \& Meidan 2014). Surprisingly, recombinant THBS1 and the CD36-binding peptide ABT898 (Garside et al. 2010b) had only modest effects on bovine LGCs viability. In contrast, despite the lack of CD36 receptors in luteal ECs, $500 \mathrm{ng} / \mathrm{mL}$ THBS1 decreased LGC numbers by $80 \%$ and promoted the 
activation of caspase-3. As expected, ABT-898 treatment did not affect the viability of luteal ECs (Farberov \& Meidan 2014). These findings suggest that THBS1 acts in luteal ECs through a CD36-independent mechanism.

Unlike CD36, the CD47 receptor is expressed in both luteal ECs and LGCs (Farberov \& Meidan 2014). The interaction of THBS1 with CD47 induced apoptosis in human umbilical vein ECs (HUVECs) and microvascular ECs (Freyberg et al. 2000, Xing et al. 2009). However, silencing of CD47 by siRNA did not rescue luteal ECs from THBS1-induced cell death (Farberov \& Meidan, unpublished data), suggesting that CD47 may not contribute to the inhibitory effects of THBS1 in luteal ECs. Another possible mechanism underlying the apoptotic actions of THBS1 in luteal cells is its ability to interact with various integrins (Calzada et al. 2004). It was found that THBS1 is a ligand for alpha 9 beta1 integrin and that the integrin binding site is located within the N-terminal domain of THBS1. The $\mathrm{N}$-terminal domain of THBS1 is also implicated in the proangiogenic activity of this molecule in microvascular ECs (Staniszewska et al. 2007). Another integrin, alpha 3 beta 1 integrin, was identified as an additional receptor for THBS1. This interaction could either inhibit or stimulate endothelial cell proliferation depending on cell origin (Chandrasekaran et al. 2000).

Another alternative pathway by which THBS1 may affect luteal endothelial cell viability is through its HSPG-binding domain (Chen et al. 2000). Interaction of THBS1 with HSPGs inhibits mitogenesis and proliferation of aortic and corneal ECs (Vogel et al. 1993). Binding of THBS1 to HSPGs results in the transmission of intracellular signals that induce apoptosis in myeloid leukemia cells (Bruel et al. 2005). HSPGs are widely expressed in ovarian GCs, and their synthesis, internalization and release are regulated by gonadotrophins (Yanagishita 1994). Immunolabeling for HSPG is very intense in luteal cells and capillary ECs of mature CL (Hasan et al. 2002), supporting a role in THBS1 action; however, this notion has not been examined experimentally in ovarian cells.

\section{Interaction of THBS1 with proangiogenic FGF2}

THBS1 is known to inhibit angiogenesis both directly and indirectly by interacting with growth factors, cytokines and proteases. One such interaction is with FGF2, a vital proangiogenic factor in the CL (Robinson et al. 2007, Yamashita et al. 2008). By binding to the FGF2 heparinbinding domain, THBS1 prevents the interaction of FGF2 with HSPGs on the cell surface and in the ECM (Fig. 2) (Colombo et al. 2010), which ultimately reduces FGF2 bioavailability and activity (Pagano et al. 2012) (Fig. 2). FGF2 is not only proangiogenic but also sustains steroidogenic cell survival and stimulates progesterone secretion when infused into bovine CL (Liebermann et al.

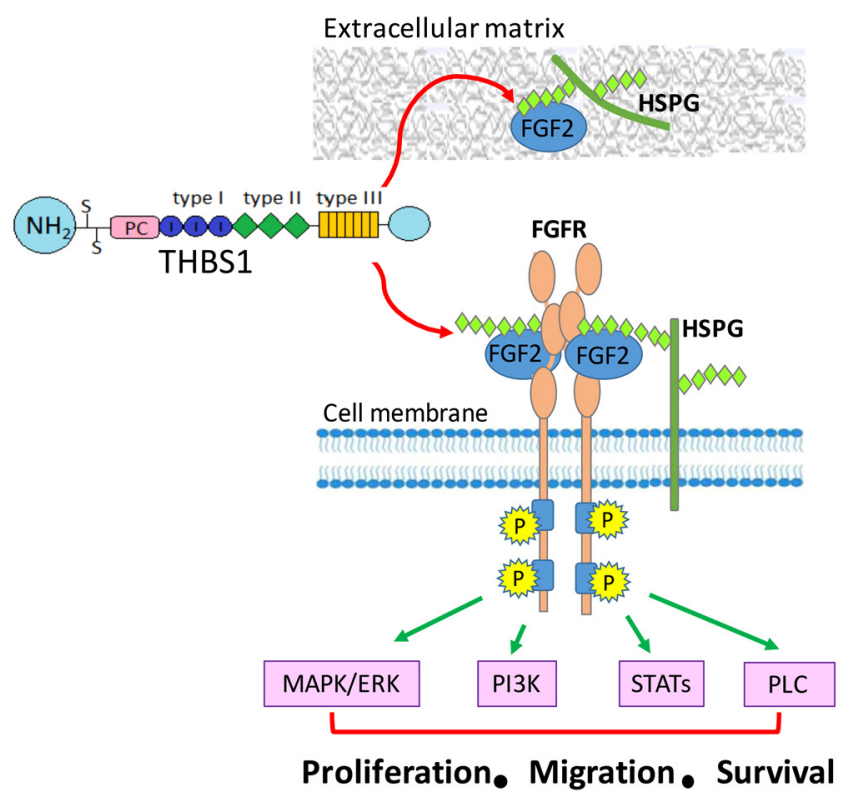

Figure 2 Schematic representation of THBS1-FGF2 interaction. Binding of FGF2 to FGFR with heparin sulfate proteoglycan (HSPG) as a cofactor induces the formation of the ternary FGF2-FGFR-HSPG complex. This complex activates the receptor tyrosine kinase domain by phosphorylating tyrosine residues. The activated receptor triggers multiple downstream signaling pathways that drive cell proliferation, migration, and survival. Type III repeats within the THBS1 sequence sequester FGF2, preventing its interaction with HSPG in the extracellular matrix and on the cell surface. Thus, THBS1 affects FGF2 internal dynamics, causing allosteric inhibition of FGF2 binding to its cognate tyrosine kinase receptors and leading to inhibition of FGF2 angiogenic activity.

1996). Studies in bovine luteal ECs showed that THBS1 and small-molecule 27, which mimics the FGF2-binding site of THBS1, inhibit FGF2-induced proliferation and migration in vitro (Zalman et al. 2012). Consistent with these results, THBS1 inhibited the phosphorylation of p44/p42 mitogen-activated protein kinase (MAPK; ERK1/2) induced by FGF2 in luteal ECs (Farberov \& Meidan, unpublished data). Furthermore, siRNA ablation of THBS1 elevates the levels of phosphorylated p44/42 (unpublished data). The antagonistic actions of FGF2 and THBS1 were further demonstrated by the ability of FGF2 to reduce basal and THBS1-induced caspase-3 levels in ECs derived from the CL (Farberov \& Meidan 2014).

Notably, THBS1 and FGF2 expression in bovine CL exhibited the most divergent induction profile by PGF2a. Whereas FGF2 was robustly induced in young $\mathrm{CL}$ (day 4) and much less in responsive CL (day 11), THBS1 was prominent in the PGF2a-responsive CL (day 11) (Zalman et al. 2012). These expression profiles suggest reciprocal regulation of FGF2 and THBS1 in luteal cells by luteinizing signals and PGF2a. This proposition was confirmed by findings demonstrating that THBS1 expression in cultured LGCs was inhibited by luteinizing 
signals (LH and insulin), whereas FGF2 expression was elevated after LH treatment and by PGF2a (Farberov \& Meidan 2014) (Fig. 1). Moreover, these two proteins are mutually inhibitory at the gene expression level, that is, THBS1 added exogenously to luteal ECs dose dependently suppresses FGF2 expression and vice-aversa (Fig. 3) (Farberov \& Meidan 2014). In agreement, THBS1 silencing elevated FGF2 levels in both luteal ECs and LGCs (Farberov \& Meidan 2014). Suppression of THBS1 expression by FGF2 was also reported in mouse breast cancer cells, but the regulatory mechanisms were not examined (Mattila et al. 2006). Intracellular responses to FGF2 are mediated by several signal transduction cascades, including the RAS-MAPK, PI3K and phospholipase C pathways (Dailey et al. 2005). The RAS-MAPK pathway regulates the expression of diverse target genes through activation of E26 transformationspecific (ETS) transcription factors (Tsang \& Dawid 2004), and several ETS sites are present in the THBS1 promoter, suggesting FGF2-induced THBS1 repression through RAS-MAPK signaling (Zabuawala et al. 2010). Activation of the PI3K/AKT pathway may also contribute to FGF2-mediated inhibition of THBS1 synthesis (Bussolati et al. 2006, Kim et al. 2006). Furthermore, FGF2 can suppress THBS1 expression via upregulation of two repressors, YY-1 (Yin Yang-1) (Santiago et al. 2001) and Id-1 (inhibitor of differentiation-1) (Passiatore et al. 2011), which were reported to bind to the THBS1 promoter (Volpert et al. 2002, Kang et al. 2004).

The results described here suggest a transcriptional and functional interplay between THBS1 and FGF2 (Figs 2 and 3). This relationship is expected to regulate angiogenesis in a luteal stage-specific manner.

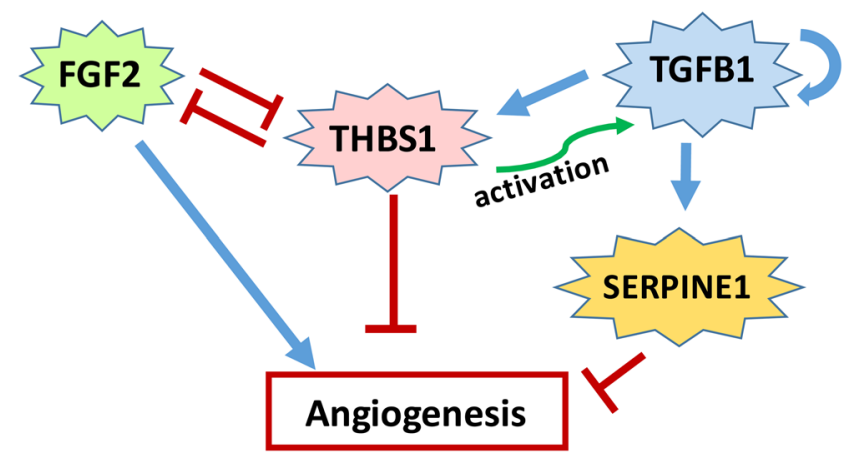

Figure 3 Proposed THBS1 network of interactions with FGF2, TGFB1 and SERPINE1 in luteal cells. THBS1 is a potent antiangiogenic factor that can directly disrupt the angiogenic properties of luteal ECs through multiple mechanisms. THBS1 also inhibit the proangiogenic actions of FGF2. These two proteins are mutually inhibitory at the gene expression level. In addition, THBS1 activates latent TGFB1, thus enabling TGFB1 signaling, which results in upregulation of SERPINE1 (encoding PAI-1). PAI-1 further promotes vascular instability. Active TGFB1 can also enhance its own mRNA expression and that of THBS1, a process that would lead to further induction of SERPINE1.

\section{THBS1-TGFB1 axis}

TGFB family members are produced as inactive complexes with latency-associated peptide (LAP) and must be activated by molecules that facilitate release from the latent complex (Robertson \& Rifkin 2013). THBS1 is the only member of the THBS family that can activate TGFB1 (Figs 3 and 4) (Murphy-Ullrich \& Poczatek 2000).

A unique motif, KRFK, situated in the type I repeats domain of THBS1 can physically interact with the LSKL sequence in LAP, resulting in the release of active TGFB1 (Ribeiro et al. 1999). The corresponding peptide from THBS2 (TRIR) does not activate TGFB1 (Murphy-Ullrich \& Poczatek 2000) (Fig. 4). Once activated, TGFB1 can bind to its cell membrane receptors (TGFBRI and TGFBRII), leading to phosphorylation of SMAD2 and SMAD3 proteins, which in turn complex with SMAD4, translocate to the nucleus and bind to SMAD response elements that regulate target gene expression (Fig. 4) (Massague 2000). Like THBS1, TGFB1 expression was induced only in mature (day 11) $\mathrm{CL}$, after PGF2a injection (Mondal et al. 2011, Farberov \& Meidan 2016). Expression of the TGFB1 downstream target SERPINE1 (Boehm et al. 1999) was also markedly upregulated by PGF2a only in day 11 CL undergoing luteolysis (Fig. 4) (Farberov \& Meidan 2016). Upregulation of SERPINE1 by luteolytic signals was also shown in ovine $\mathrm{CL}$ (Romero et al. 2013). Recently, it was demonstrated that THBS1 can activate latent TGFB1 in bovine luteal ECs (Farberov \& Meidan 2016). THBS1 elevated SERPINE1 expression in these cells, an effect that was abolished by a TGFBRI kinase inhibitor. Additionally, THBS1 markedly increased the effects of latent TGFB1 on SMAD2 phosphorylation (phospho-SMAD2) and SERPINE1 upregulation. THBS1 silencing also resulted in reduced SERPINE1 mRNA and phospho-SMAD2 levels. Lastly, THBS1 actions on SERPINE1 were inhibited partially by LSKL peptide (Farberov \& Meidan 2016) (Fig. 4).

The role of TGFB1 in apoptotic cell death is context dependent (Sanchez-Capelo 2005). In bovine luteal ECs, TGFB1 promotes apoptosis (Maroni \& Davis 2011, Farberov \& Meidan 2016), limits cell growth and disrupts capillary morphogenesis and endothelial barrier function (Maroni \& Davis 2011). TGFB1 also reduces the viability of cells and activates caspase-3, whereas inhibition of TGFBRI eliminates this proapoptotic effect (Farberov \& Meidan 2016). Importantly, although THBS1 can activate TGFB1, the proapoptotic effect of THBS1 is not mediated via TGFB1 in luteal ECs. THBS1 is a significantly more potent inhibitor of cell viability than TGFB1, and this effect is not abolished by a TGFBRI inhibitor (Farberov \& Meidan 2016).

In addition to the SMAD-mediated canonical TGFB1 signaling pathway, TGFB1 may signal through all three MAPK pathways, extracellular signal-regulated kinases, c-Jun N-terminal kinases and p38 MAPK (Zhang 2009). 


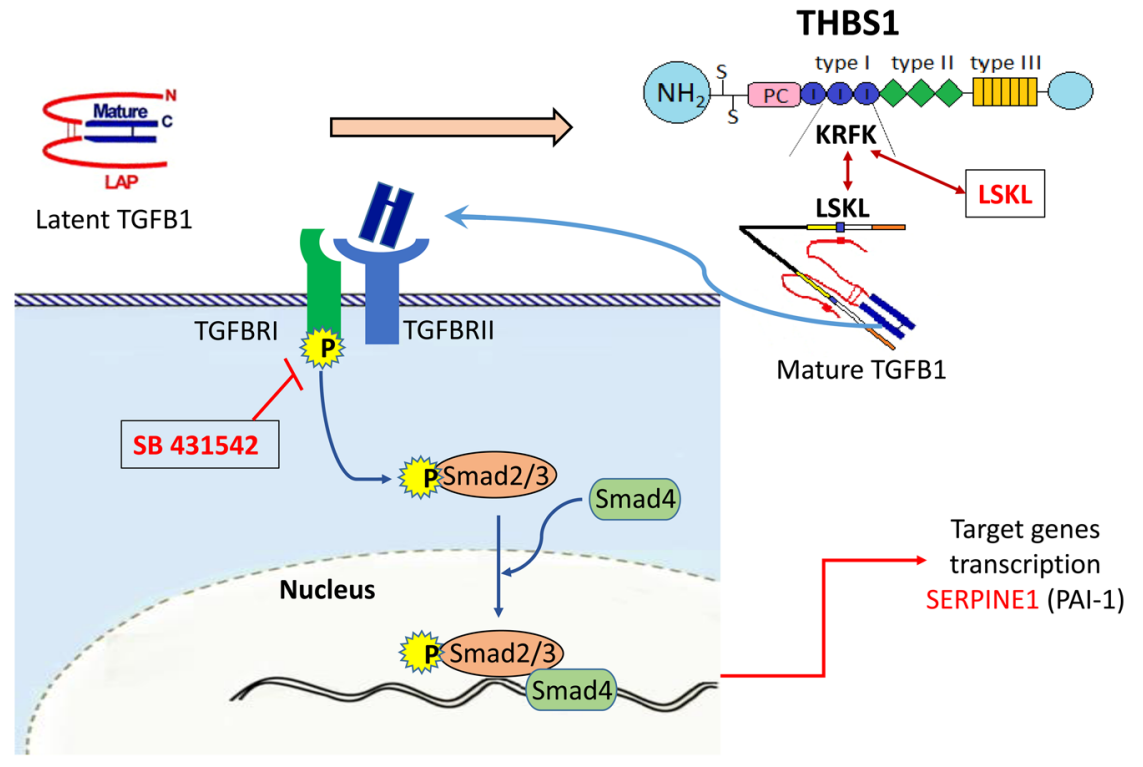

Figure 4 Activation of TGFB1 signaling pathway by THBS1. TGFB1 is produced in a latent form consisting of the mature TGF-beta dimer and a non-covalently related latencyassociated peptide (LAP). Activation by THBS1 involves a WXXW motif in type 1 repeats for binding to the mature TGFB1 dimer and a proposed second recognition sequence, KRFK, which binds to a conserved sequence (LSKL) near the amino-terminus of LAP. These sequences disrupt the non-covalent interactions between LAP and TGFB1, thereby releasing the mature TGFB1 for receptor binding. Active TGFB1 binds to a type II receptor that recruits and phosphorylates type I receptor. The type I receptor then phosphorylates receptor-regulated SMADs (SMAD2 and SMAD3), which can bind the common mediator SMAD4 and subsequently translocate into the nucleus. In the nucleus, these SMADs interact with other transcription factors to upregulate the expression of target genes such as SERPINE1 (PAI-1). SB431542 is a TGFB1 receptor-1 kinase inhibitor.
Rapid activation of p38 MAPK by TGFB1 was observed in luteal ECs; however, this pathway did not modulate the proapoptotic effect of TGFB1 (Farberov \& Meidan 2016). THBS1 can also activate the p38 pathway in these cells, but with slower kinetics than TGFB1 (Farberov \& Meidan 2016), indicating that this may be an indirect effect. Inhibition of the p38 pathway augmented the proapoptotic actions of THBS1 (Farberov \& Meidan 2016). Activation of p38 kinase enhances cell survival in response to DNA damage, possibly by promoting DNA repair prior to a mitotic catastrophe (Thornton \& Rincon 2009). Thus, this pathway may be initiated as a protective mechanism against DNA damage induced by proapoptotic THBS1.

TGFB1 was found to induce the expression of THBS1 in luteal ECs (Farberov \& Meidan 2016) (Fig. 4) as well as in other cell types (Negoescu et al. 1995, Bein et al. 2004, Flugel-Koch et al. 2004). In addition to THBS1 stimulation, TGFB1 also upregulates its own mRNA levels in these cells (Fig. 3) (Farberov \& Meidan 2016), thus creating a positive feedback loop that leads to amplification of proapoptotic and antiangiogenic effects during luteolysis.

\section{Role of THBS1 in matrix remodeling}

Regulation of multiple proteolytic enzymes by THBS1 contributes to physiological and pathological tissue remodeling (Sweetwyne \& Murphy-Ullrich 2012). Two interrelated proteolytic systems are involved in matrix remodeling, the plasminogen activation (PA) system and the matrix metalloproteinase (MMP) system. Several studies have shown that THBS1 is involved in regulating the balance between MMPs and MMP inhibitors (tissue inhibitors of metaloproteases (TIMPs)). THBS1 prevents the activation of MMPs via type I repeats (Bein \& Simons 2000) and suppresses the activation of MMP9 by binding to its inactive form (Rodriguez-Manzaneque et al. 2001). In HUVEC cells, inhibition of MMP activation decreased proangiogenic and promigratory effects induced by platelet microvesicles (Sun et al. 2017). On the other hand, THBS1 has also been reported to increase MMP2 and -9 activation in several tumor cells (Ren et al. 2006) and vascular smooth muscle cells (Lee et al. 2003). This dual behavior of THBS1 is probably mediated by distinct domains with opposite functions. These domains may also selectively activate or suppress the invasive behavior of vascular endothelium (Taraboletti et al. 2000).

THBS1 is also able to regulate the PA system. Upregulation of the SERPINE1 gene product plasminogen activator inhibitor type 1 (PAI-1) by THBS1 has been demonstrated in several tumor cells (Albo et al. 1994, 1999), microvascular ECs (Bagavandoss et al. 1993), and recently in ECs derived from the $\mathrm{CL}$ (Farberov \& Meidan 2016). PAI-1 is the primary inhibitor of tissue plasminogen activator (tPA) and urokinase plasminogen activator (uPA). Inhibition of uPA/tPA blocks plasminogen-toplasmin conversion as well as plasmin-dependent MMP activation (Pepper 2001). Additionally, PAI-1 can bind to vitronectin (VN), which leads to cell detachment and apoptosis (Chen et al. 2008).

Extensive tissue remodeling takes place in the ovary during follicular development, follicular rupture, CL formation and $C L$ regression (Smith et al. 2002). Both MMP and PA systems have been implicated in $\mathrm{CL}$ formation and regression (Kliem et al. 2007). MMP mRNA expression was significantly increased in bovine $\mathrm{CL}$ during PGF2a-induced luteolysis, whereas TIMP2 was decreased (Kliem et al. 2007). As mentioned, PGF2a-induced luteolysis also affects PAI-1 expression 


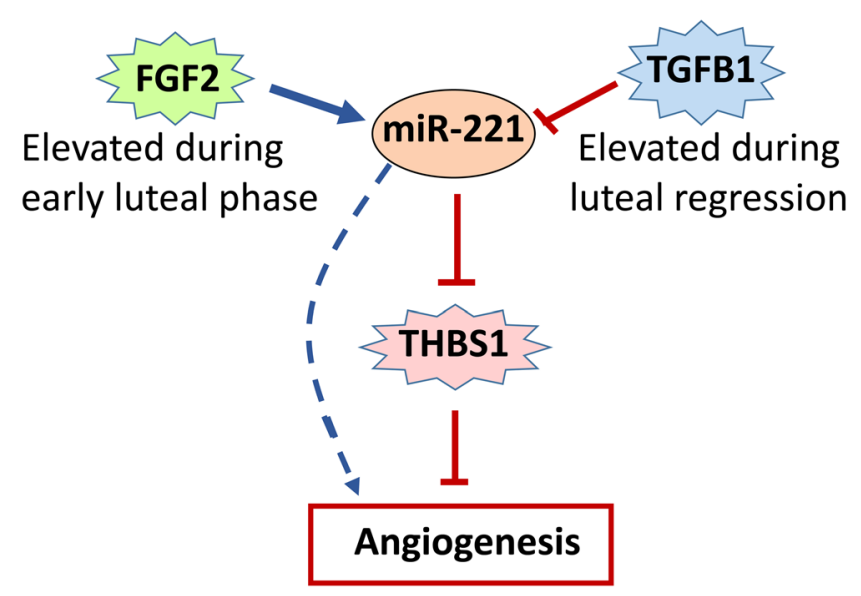

Figure 5 Regulation of miR-221 expression and its role in luteal cells. miR-221 is highly expressed in luteal cells and in $\mathrm{CL}$, where it effectively suppresses antiangiogenic THBS1. TGFB1 and FGF2 inversely modulate miR-221 levels, providing a possible explanation for their reciprocal control of THBS1 expression. Consistent with THBS1 inhibition and consequent SERPINE1 downregulation, miR-221 induces luteal endothelial cell migration, proliferation and survival, thereby promoting angiogenesis.

in a pattern resembling that of THBS1, a small and transient elevation during early $\mathrm{CL}$ formation and $\mathrm{a}$ substantial cumulative induction in regressing $\mathrm{CL}$ (Kliem et al. 2007, Farberov \& Meidan 2016). Functionally, PAI-1 inhibits luteal EC-VN interactions either by the VN-binding domain or through antiprotease activity (Farberov \& Meidan 2018), thereby affecting cell matrix adhesion required for cell survival.

These results are consistent with the following molecular cascade of events in bovine $\mathrm{CL}$ during PGF2a-induced luteolysis. (i) THBS1 and TGFB1 are directly induced by PGF2a in luteal cells. (ii) THBS1 then activates latent TGFB1, leading to upregulation of SERPINE1 (Figs 3 and 4). THBS1, TGFB1 and PAI-1 are expected to promote vascular instability as well as apoptosis and matrix remodeling in regressing CL.

\section{Regulation of THBS1 expression by microRNAs}

In addition to transcriptional regulation by FGF2 and TGFB1, several studies have identified a number of miRNAs that can modulate THBS1 in different cell types (Vincenti et al. 2011, Dogar et al. 2014, Feng et al. 2015). Studies have suggested that miRNAs are critical for ovarian function by regulating folliculogenesis, oocyte-cumulus cell interaction, GC function and the development, maintenance and regression of the CL (Hossain et al. 2009, Christenson 2010, Maalouf et al. 2016). Recently, miR-221 was identified as a key regulator of THBS1 expression and function in ECs derived from bovine CL (Farberov \& Meidan 2018). This miRNA, highly expressed in luteal cells and bovine $\mathrm{CL}$, effectively reduced THBS1 levels and subsequently inhibited SERPINE1 mRNA (Farberov \& Meidan 2018). The miR-221/222 cluster plays an important role in vascular biology, and miR-221 is among the most frequently upregulated miRNAs in human cancers (Vincenti et al. 2011, Nicoli et al. 2012, Lupini et al. 2013). Overexpression of miR-221 in luteal ECs was proangiogenic, consistent with THBS1 suppression (Fig. 5) (Farberov \& Meidan 2018). Importantly, FGF2 and TGFB1 were found to reciprocally regulate miR-221 in these cells. FGF2 elevates miR-221 levels, which may account for negative regulation of THBS1 (Fig. 5). Conversely, TGFB1, which stimulates THBS1, significantly reduces miR-221 levels (Fig. 5). Furthermore, FGF2 enhances the suppression of THBS1 caused by miR-221 mimic and prevents the increase in THBS1 induced by miR-221 inhibitor (Farberov \& Meidan 2018). Importantly, FGF2 treatment also elevates miR-221 in bovine theca cells (Robinson et al. 2018). In contrast to FGF2, TGFB1 reverses the inhibitory effect of miR-221 mimic on THBS1 and enhances the upregulation of THBS1 induced by miR-221 inhibitor (Farberov \& Meidan 2018). These data support the contention that FGF2 and TGFB1 modulate THBS1 expression via miR-221 (Fig. 5).

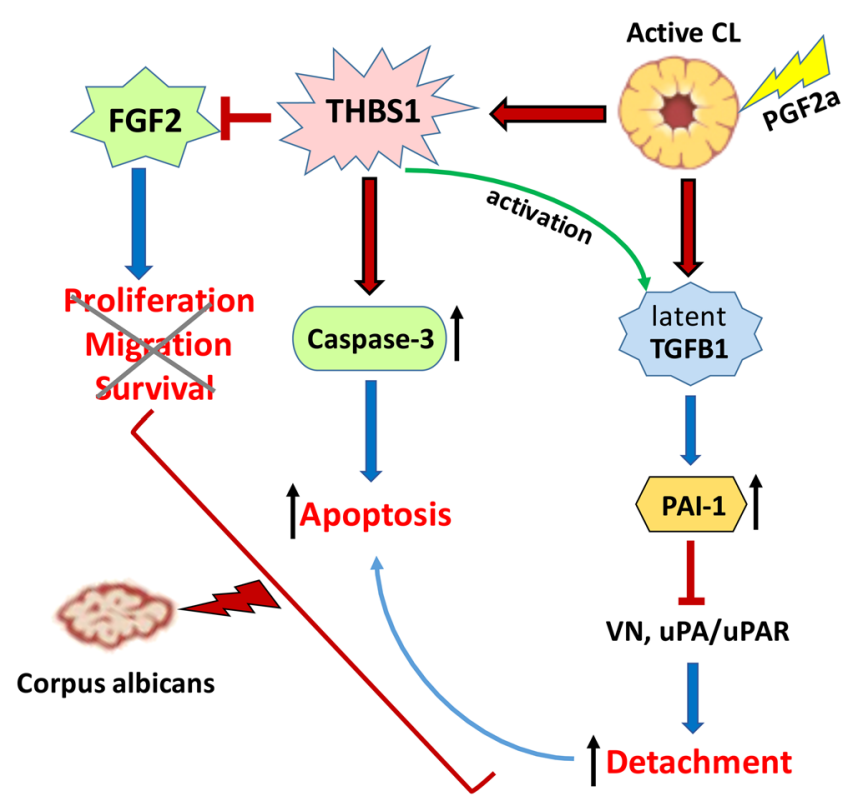

Figure 6 Illustrative summary of thrombospondin-1 (THBS1) actions in luteolysis. THBS1 and latent TGFB1 are directly induced by PGF2a in mature CL. THBS1, a multimodular protein, exerts its antiangiogenic activity through multiple mechanisms: 1 . apoptosis by activation of caspase-3; 2. interactions with two other vital luteal factors, FGF2 and TGFB; 3. suppression of FGF2 expression and its angiogenic activities; 4 . activation of latent TGFB1, thus enabling TGFB1 signaling, resulted in upregulation of SERPINE1 (PAI-1). Disrupting the interaction between the uPA-uPA receptor complex and vitronectin by PAI-1 interrupts cell adhesion, further promoting cell death. Together, these actions of THBS1 contribute to a cascade of events leading to the irreversible demise of the CL. 
Based on these findings, miR-221 is expected to be elevated during $C L$ formation and reduced in late and regressed $\mathrm{CL}$. Indeed, small RNA next-generation sequencing demonstrated that miR-221 levels vary in $\mathrm{CL}$ during the estrous cycle, with lower expression in late and regressed bovine $C L$ and abundant expression in early CL (Gecaj et al. 2017). This temporal expression profile of miR-221 in CL is also supported by a study reporting that miR-221 expression in bovine plasma was lower on day 16 compared with day 8 of the estrous cycle (Ioannidis \& Donadeu 2016). Similarly in sheep, greater miR-221 expression was found in early $C L$ relatively to dominant follicle and reduced levels were found in late $\mathrm{CL}$ (McBride et al. 2012).

These findings suggest that miR-221 is regulated in a physiologically significant manner, affecting THBS1 expression throughout the cycle. Altering THBS1 levels can modulate vascular function in the $\mathrm{CL}$, shifting from angiogenesis in young $\mathrm{CL}$ to vascular instability in latecycle CL.

\section{Conclusions and perspectives}

We present evidence that THBS1 is essential for luteal fate determination (regression or maintenance). Interactions with multiple membrane proteins, growth factors, extracellular matrix components and miRNAs regulated multiple pathways involved in luteal cell proliferation, migration and apoptosis (Fig. 6). Identifying the THBS1 network of interactions with FGF2, TGFB1 and SERPINE1 has enhanced our understanding of the molecular control of angiogenesis and cell survival in follicles and the CL. Crosstalk between pro- and antiangiogenic processes enables THBS1 to inhibit angiogenesis by antagonizing survival pathways while also activating apoptotic pathways (Fig. 6). Recent investigations showing that miR-221 regulates THBS1 expression in luteal cells provide new prospects for managing luteal cell fate and may facilitate the future development of effective and practical methods to fully regress the $\mathrm{CL}$ or optimize CL maintenance during early pregnancy. Further efforts are also needed to develop specific and potent therapeutic interventions that either downregulate or upregulate THBS1 levels to promote or inhibit angiogenesis, which may prove useful in tackling angiogenesis-dependent diseases.

\section{Declaration of interest}

Rina Meidan is a member of the Editorial Board of Reproduction. Rina Meidan was not involved in the review or editorial process for this paper, on which she is listed as an author. The other authors have nothing to declare.

\section{Funding}

This research was supported by grant no. IS-3987-07 and IS-4799-15 from the BARD (Binational Agricultural Research \& Development Fund). The grant was awarded to $\mathrm{R} \mathrm{M}$ and funding played no role in the planning, writing, and decision to submit this manuscript.

\section{References}

Adams J \& Lawler J 1993 The thrombospondin family. Current Biology 3 188-190. (https://doi.org/10.1016/0960-9822(93)90270-X)

Adams JC \& Lawler J 2004 The thrombospondins. International Journal of Biochemistry and Cell Biology 36 961-968. (https://doi.org/10.1016/j. biocel.2004.01.004)

Adams JC \& Lawler J 2011 The thrombospondins. Cold Spring Harbor Perspectives in Biology 3 a009712. (https://doi.org/10.1101/cshperspect. a009712)

Albo D, Arnoletti JP, Castiglioni A, Granick MS, Solomon MP, Rothman VL \& Tuszynski GP 1994 Thrombospondin (TSP) and transforming growth factor beta 1 (TGF-beta) promote human A549 lung carcinoma cell plasminogen activator inhibitor type 1 (PAI-1) production and stimulate tumor cell attachment in vitro. Biochemical and Biophysical Research Communications 203 857-865. (https://doi.org/10.1006/ bbrc.1994.2262)

Albo D, Berger DH, Vogel J \& Tuszynski GP 1999 Thrombospondin-1 and transforming growth factor beta-1 upregulate plasminogen activator inhibitor type 1 in pancreatic cancer. Journal of Gastrointestinal Surgery 3 411-417. (https://doi.org/10.1016/S1091-255X(99)80058-4)

Bagavandoss P, Kaytes P, Vogeli G, Wells PA \& Wilks JW 1993 Recombinant truncated thrombospondin-1 monomer modulates endothelial cell plasminogen activator inhibitor 1 accumulation and proliferation in vitro. Biochemical and Biophysical Research Communications 192 325-332. (https://doi.org/10.1006/bbrc.1993.1418)

Bagavandoss P, Sage EH \& Vernon RB 1998 Secreted protein, acidic and rich in cysteine (SPARC) and thrombospondin in the developing follicle and corpus luteum of the rat. Journal of Histochemistry and Cytochemistry 46 1043-1049. (https://doi.org/10.1177/002215549804600908)

Basavaraja R, Przygrodzka E, Pawlinski B, Gajewski Z, Kaczmarek MM \& Meidan R 2017 Interferon-tau promotes luteal endothelial cell survival and inhibits specific luteolytic genes in bovine corpus luteum. Reproduction 154 559-568. (https://doi.org/10.1530/REP-17-0290)

Bein K \& Simons M 2000 Thrombospondin type 1 repeats interact with matrix metalloproteinase 2. Regulation of metalloproteinase activity. Journal of Biological Chemistry 275 32167-32173. (https://doi. org/10.1074/jbc.M003834200)

Bein K, Odell-Fiddler ET \& Drinane M 2004 Role of TGF-beta1 and JNK signaling in capillary tube patterning. American Journal of Physiology: Cell Physiology $287 \quad$ C1012-C1022. (https://doi.org/10.1152/ ajpcell.00101.2004)

Berisha B, Schams D, Rodler D, Sinowatz F \& Pfaffl MW 2016 Expression and localization of members of the thrombospondin family during final follicle maturation and corpus luteum formation and function in the bovine ovary. Journal of Reproduction and Development 62 501-510. (https://doi.org/10.1262/jrd.2016-056)

Boehm JR, Kutz SM, Sage EH, Staiano-Coico L \& Higgins PJ 1999 Growth state-dependent regulation of plasminogen activator inhibitor type-1 gene expression during epithelial cell stimulation by serum and transforming growth factor- $\beta 1$. Journal of Cellular Physiology 181 96-106. (https://doi.org/10.1002/(SICl)10974652(199910)181:1<96::AID-JCP10>3.0.CO;2-I)

Bornstein P 2001 Thrombospondins as matricellular modulators of cell function. Journal of Clinical Investigation 107 929-934. (https://doi. org/10.1172/JCI12749)

Bornstein P 2009 Thrombospondins function as regulators of angiogenesis. Journal of Cell Communication and Signaling 3 189-200. (https://doi. org/10.1007/s12079-009-0060-8)

Bott RC, Ashley RL, Henkes LE, Antoniazzi AQ, Bruemmer JE, Niswender GD, Bazer FW, Spencer TE, Smirnova NP, Anthony RV et al. 2010 Uterine vein infusion of interferon tau (IFNT) extends luteal 
life span in ewes. Biology of Reproduction 82 725-735. (https://doi. org/10.1095/biolreprod.109.079467)

Brown EJ \& Frazier WA 2001 Integrin-associated protein (CD47) and its ligands. Trends in Cell Biology 11 130-135. (https://doi.org/10.1016/ S0962-8924(00)01906-1)

Bruel A, Touhami-Carrier M, Thomaidis A \& Legrand C 2005 Thrombospondin-1 (TSP-1) and TSP-1-derived heparin-binding peptides induce promyelocytic leukemia cell differentiation and apoptosis. Anticancer Research 25 757-764.

Bussolati B, Assenzio B, Deregibus MC \& Camussi G 2006 The proangiogenic phenotype of human tumor-derived endothelial cells depends on thrombospondin-1 downregulation via phosphatidylinositol 3-kinase/Akt pathway. Journal of Molecular Medicine 84 852-863. (https://doi.org/10.1007/s00109-006-0075-z)

Calzada MJ, Annis DS, Zeng B, Marcinkiewicz C, Banas B, Lawler J, Mosher DF \& Roberts DD 2004 Identification of novel beta1 integrin binding sites in the type 1 and type 2 repeats of thrombospondin-1. Journal of Biological Chemistry 279 41734-41743. (https://doi. org/10.1074/jbc.M406267200)

Carlson CB, Lawler J \& Mosher DF 2008 Structures of thrombospondins. Cellular and Molecular Life Sciences 65 672-686. (https://doi org/10.1007/s00018-007-7484-1)

Chandrasekaran L, He C-Z, Al-Barazi H, Krutzsch HC, Iruela-Arispe ML \& Roberts DD 2000 Cell contact-dependent activation of $\alpha 3 \beta 1$ integrin modulates endothelial cell responses to thrombospondin-1. Molecular Biology of the Cell 11 2885-2900. (https://doi.org/10.1091/ mbc.11.9.2885)

Chen H, Herndon ME \& Lawler J 2000 The cell biology of thrombospondin-1. Matrix Biology 19 597-614. (https://doi.org/10.1016/ S0945-053X(00)00107-4)

Chen SC, Henry DO, Reczek PR \& Wong MK 2008 Plasminogen activator inhibitor-1 inhibits prostate tumor growth through endothelial apoptosis. Molecular Cancer Therapeutics 7 1227-1236. (https://doi. org/10.1158/1535-7163.MCT-08-0051)

Christenson LK 2010 MicroRNA control of ovarian function. Animal Reproduction 7 129-133.

Colombo G, Margosio B, Ragona L, Neves M, Bonifacio S, Annis DS, Stravalaci M, Tomaselli S, Giavazzi R, Rusnati M et al. 2010 Non-peptidic thrombospondin-1 mimics as fibroblast growth factor-2 inhibitors: an integrated strategy for the development of new antiangiogenic compounds. Journal of Biological Chemistry 285 8733-8742. (https:// doi.org/10.1074/jbc.M109.085605)

Dailey L, Ambrosetti D, Mansukhani A \& Basilico C 2005 Mechanisms underlying differential responses to FGF signaling. Cytokine and Growth Factor Reviews 16 233-247. (https://doi.org/10.1016/j. cytogfr.2005.01.007)

Dogar AM, Semplicio G, Guennewig B \& Hall J 2014 Multiple microRNAs derived from chemically synthesized precursors regulate thrombospondin 1 expression. Nucleic Acid Therapeutics 24 149-159. (https://doi.org/10.1089/nat.2013.0467)

Dreyfus M, Dardik R, Suh BS, Amsterdam A \& Lahav J 1992 Differentiationcontrolled synthesis and binding of thrombospondin to granulosa cells. Endocrinology $\mathbf{1 3 0}$ 2565-2570. (https://doi.org/10.1210/ endo.130.5.1374008

Farberov S \& Meidan R 2014 Functions and transcriptional regulation of thrombospondins and their interrelationship with fibroblast growth factor-2 in bovine luteal cells. Biology of Reproduction 91 58. (https:// doi.org/10.1095/biolreprod.114.121020)

Farberov S \& Meidan R 2016 Thrombospondin-1 affects bovine luteal function via transforming growth factor-beta1-dependent and independent actions. Biology of Reproduction 94 25. (https://doi. org/10.1095/biolreprod.115.135822)

Farberov S \& Meidan R 2018 Fibroblast growth factor-2 and transforming growth factor-beta1 oppositely regulate miR-221 that targets thrombospondin-1 in bovine luteal endothelial cells. Biology of Reproduction 98 366-375. (https://doi.org/10.1093/biolre/iox167)

Feng N, Wang Z, Zhang Z, He X, Wang C \& Zhang L 2015 miR-487b promotes human umbilical vein endothelial cell proliferation, migration, invasion and tube formation through regulating THBS1. Neuroscience Letters 591 1-7. (https://doi.org/10.1016/j.neulet.2015.02.002)

Flugel-Koch C, Ohlmann A, Fuchshofer R, Welge-Lussen U \& Tamm ER 2004 Thrombospondin-1 in the trabecular meshwork: localization in normal and glaucomatous eyes, and induction by TGF-beta1 and dexamethasone in vitro. Experimental Eye Research 79 649-663. (https:// doi.org/10.1016/j.exer.2004.07.005)

Freyberg MA, Kaiser D, Graf R, Vischer P \& FriedI P 2000 Integrin-associated protein and thrombospondin-1 as endothelial mechanosensitive death mediators. Biochemical and Biophysical Research Communications 271 584-588. (https://doi.org/10.1006/bbrc.2000.2678)

Garside SA, Harlow CR, Hillier SG, Fraser HM \& Thomas FH 2010a Thrombospondin-1 inhibits angiogenesis and promotes follicular atresia in a novel in vitro angiogenesis assay. Endocrinology 151 1280-1289. (https://doi.org/10.1210/en.2009-0686)

Garside SA, Henkin J, Morris KD, Norvell SM, Thomas FH \& Fraser HM $2010 b$ A thrombospondin-mimetic peptide, ABT-898, suppresses angiogenesis and promotes follicular atresia in pre- and early-antral follicles in vivo. Endocrinology 151 5905-5915. (https://doi.org/10.1210/ en.2010-0283)

Gecaj RM, Schanzenbach CI, Kirchner B, Pfaffl MW, Riedmaier I, TweedieCullen RY \& Berisha B 2017 The dynamics of microRNA transcriptome in bovine corpus luteum during its formation, function, and regression. Frontiers in Genetics 8 213. (https://doi.org/10.3389/fgene.2017.00213)

Greenaway J, Gentry PA, Feige JJ, LaMarre J \& Petrik JJ 2005 Thrombospondin and vascular endothelial growth factor are cyclically expressed in an inverse pattern during bovine ovarian follicle development. Biology of Reproduction 72 1071-1078. (https://doi. org/10.1095/biolreprod.104.031120)

Hasan S, Hosseini G, Princivalle M, Dong JC, Birsan D, Cagide C \& de Agostini Al 2002 Coordinate expression of anticoagulant heparan sulfate proteoglycans and serine protease inhibitors in the rat ovary: a potent system of proteolysis control. Biology of Reproduction $\mathbf{6 6}$ 144-158. (https://doi.org/10.1095/biolreprod66.1.144)

Higuchi T, Fujiwara H, Yamada S, Tatsumi K, Kataoka N, Itoh K, Maeda M, Fujita J \& Fujii S 1999 Co-expression of integrin-associated protein (IAP/ CD47) and its ligand thrombospondin-1 on human granulosa and large luteal cells. Molecular Human Reproduction 5 920-926. (https://doi. org/10.1093/molehr/5.10.920)

Hossain MM, Ghanem N, Hoelker M, Rings F, Phatsara C, Tholen E, Schellander K \& Tesfaye D 2009 Identification and characterization of miRNAs expressed in the bovine ovary. BMC Genomics 10 443. (https:// doi.org/10.1186/1471-2164-10-443)

Ioannidis J \& Donadeu FX 2016 Circulating microRNA profiles during the bovine oestrous cycle. PLoS ONE 11 e0158160. (https://doi.org/10.1371/ journal.pone.0158160)

Jimenez B, Volpert OV, Crawford SE, Febbraio M, Silverstein RL \& Bouck N 2000 Signals leading to apoptosis-dependent inhibition of neovascularization by thrombospondin-1. Nature Medicine 6 41-48. (https://doi.org/10.1038/71517)

Juengel JL, Garverick HA, Johnson AL, Youngquist RS \& Smith MF 1993 Apoptosis during luteal regression in cattle. Endocrinology 132 249-254. (https://doi.org/10.1210/endo.132.1.8419126)

Kang JH, Chang SY, Yeom DH, Kim SA, Um SJ \& Hong KJ 2004 Weakening of the repressive YY-1 site on the thrombospondin-1 promoter via c-Jun/ YY-1 interaction. Experimental and Molecular Medicine 36 300-310. (https://doi.org/10.1038/emm.2004.41)

Kim M-S, Oh YJ, Lee S, Kim JE, Kim KH \& Chung JH 2006 Ultraviolet radiation attenuates thrombospondin 1 expression via PI3K-Akt activation in human keratinocytes. Photochemistry and Photobiology $\mathbf{8 2}$ 645-650. (https://doi.org/10.1562/2005-09-29-RA-702)

Kliem H, Welter H, Kraetzl WD, Steffl M, Meyer HH, Schams D \& Berisha B 2007 Expression and localisation of extracellular matrix degrading proteases and their inhibitors during the oestrous cycle and after induced luteolysis in the bovine corpus luteum. Reproduction $\mathbf{1 3 4}$ 535-547. (https://doi.org/10.1530/REP-06-0172)

Kvansakul M, Adams JC \& Hohenester E 2004 Structure of a thrombospondin C-terminal fragment reveals a novel calcium core in the type 3 repeats. EMBO Journal 23 1223-1233. (https://doi.org/10.1038/ sj.emboj.7600166)

Kyriakides TR, Zhu Y-H, Smith LT, Bain SD, Yang Z, Lin MT, Danielson KG, lozzo RV, LaMarca M \& McKinney CE 1998 Mice that lack thrombospondin 2 display connective tissue abnormalities that are associated with disordered collagen fibrillogenesis, an increased vascular density, and a bleeding diathesis. Journal of Cell Biology $\mathbf{1 4 0}$ 419-430. (https://doi.org/10.1083/jcb.140.2.419) 
Lauderdale JW 2009 ASAS centennial paper: contributions in the Journal of Animal Science to the development of protocols for breeding management of cattle through synchronization of estrus and ovulation. Journal of Animal Science 87 801-812. (https://doi.org/10.2527/ jas.2008-1407)

Lawler J 2000 The functions of thrombospondin-1 and-2. Current Opinion in Cell Biology 12 634-640. (https://doi.org/10.1016/S09550674(00)00143-5)

Lawler J, Sunday M, Thibert V, Duquette M, George EL, Rayburn H \& Hynes RO 1998 Thrombospondin-1 is required for normal murine pulmonary homeostasis and its absence causes pneumonia. Journal of Clinical Investigation 101 982-992. (https://doi.org/10.1172/JCI1684)

Lawler J, Miao WM, Duquette M, Bouck N, Bronson RT \& Hynes RO 2001 Thrombospondin-1 gene expression affects survival and tumor spectrum of p53-deficient mice. American Journal of Pathology 159 1949-1956. (https://doi.org/10.1016/S0002-9440(10)63042-8)

Lee T, Esemuede N, Sumpio BE \& Gahtan V 2003 Thrombospondin-1 induces matrix metalloproteinase-2 activation in vascular smooth muscle cells. Journal of Vascular Surgery 38 147-154. (https://doi.org/10.1016/ S0741-5214(02)75468-2)

Liebermann J, Schams D \& Miyamoto A 1996 Effects of local growth factors on the secretory function of bovine corpus luteum during the oestrous cycle and pregnancy in vitro. Reproduction, Fertility and Development 8 1003-1011. (https://doi.org/10.1071/RD9961003)

Lupini L, Bassi C, Ferracin M, Bartonicek N, D'Abundo L, Zagatti B, Callegari E, Musa G, Moshiri F, Gramantieri L et al. 2013 miR-221 affects multiple cancer pathways by modulating the level of hundreds messenger RNAs. Frontiers in Genetics 4 64. (https://doi.org/10.3389/ fgene.2013.00064)

Maalouf SW, Smith CL \& Pate JL 2016 Changes in microRNA expression during maturation of the bovine corpus luteum: regulation of luteal cell proliferation and function by microRNA-34a. Biology of Reproduction 94 71. (https://doi.org/10.1095/biolreprod.115.135053)

Maroni D \& Davis JS 2011 TGFB1 disrupts the angiogenic potential of microvascular endothelial cells of the corpus luteum. Journal of Cell Science 124 2501-2510. (https://doi.org/10.1242/jcs.084558)

Massague J 2000 How cells read TGF-beta signals. Nature Reviews Molecular Cell Biology 1 169-178. (https://doi.org/10.1038/35043051)

Mattila MM, Tarkkonen KM, Seppanen JA, Ruohola JK, Valve EM \& Harkonen PL 2006 Androgen and fibroblast growth factor 8 (FGF8) downregulation of thrombospondin 1 (TSP1) in mouse breast cancer cells. Molecular and Cellular Endocrinology 253 36-43. (https://doi. org/10.1016/j.mce.2006.04.007)

McBride D, Carre W, Sontakke SD, Hogg CO, Law A, Donadeu FX \& Clinton M 2012 Identification of miRNAs associated with the follicularluteal transition in the ruminant ovary. Reproduction 144 221-233. (https://doi.org/10.1530/REP-12-0025)

McCracken JA, Custer EE \& Lamsa JC 1999 Luteolysis: a neuroendocrinemediated event. Physiological Reviews 79 263-323. (https://doi. org/10.1152/physrev.1999.79.2.263)

Meidan R, Girsh E, Mamluk R, Levy N \& Farberov S 2017 Luteolysis in Ruminants: Past Concepts, New Insights, and Persisting Challenges, The Life Cycle of the Corpus Luteum, pp 159-182. Springer International Publishing: Switzerland.

Miyamoto A, Shirasuna K, Shimizu T, Bollwein H \& Schams D 2010 Regulation of corpus luteum development and maintenance: specific roles of angiogenesis and action of prostaglandin F2alpha. Society of Reproduction and Fertility Supplement 67 289-304.

Mondal M, Schilling B, Folger J, Steibel JP, Buchnick H, Zalman Y, Ireland JJ, Meidan R \& Smith GW 2011 Deciphering the luteal transcriptome: potential mechanisms mediating stage-specific luteolytic response of the corpus luteum to prostaglandin F(2)alpha. Physiological Genomics 43 447-456. (https://doi.org/10.1152/physiolgenomics.00155.2010)

Murphy-Ullrich JE \& Poczatek M 2000 Activation of latent TGF-beta by thrombospondin-1: mechanisms and physiology. Cytokine and Growth Factor Reviews 11 59-69. (https://doi.org/10.1016/S13596101(99)00029-5)

Negoescu A, Lafeuillade B, Pellerin S, Chambaz EM \& Feige JJ 1995 Transforming growth factors beta stimulate both thrombospondin-1 and CISP/thrombospondin-2 synthesis by bovine adrenocortical cells. Experimental Cell Research 217 404-409. (https://doi.org/10.1006/ excr.1995.1103)
Nicholson AC, Han J, Febbraio M, Silversterin RL \& Hajjar DP 2001 Role of CD36, the macrophage class B scavenger receptor, in atherosclerosis. Annals of the New York Academy of Sciences 947 224-228. (https://doi. org/10.1111/j.1749-6632.2001.tb03944.x)

Nicoli S, Knyphausen CP, Zhu LJ, Lakshmanan A \& Lawson ND 2012 miR-221 is required for endothelial tip cell behaviors during vascular development. Developmental Cell 22 418-429. (https://doi. org/10.1016/j.devcel.2012.01.008)

Niswender GD, Juengel JL, Silva PJ, Rollyson MK \& McIntush EW 2000 Mechanisms controlling the function and life span of the corpus luteum. Physiological Reviews 80 1-29. (https://doi.org/10.1152/ physrev.2000.80.1.1)

Pagano K, Torella R, Foglieni C, Bugatti A, Tomaselli S, Zetta L, Presta M, Rusnati M, Taraboletti G, Colombo G et al. 2012 Direct and allosteric inhibition of the FGF2/HSPGs/FGFR1 ternary complex formation by an antiangiogenic, thrombospondin-1-mimic small molecule. PLOS ONE 7 e36990. (https://doi.org/10.1371/journal.pone.0036990)

Passiatore G, Gentilella A, Rom S, Pacifici M, Bergonzini V \& Peruzzi F 2011 Induction of Id-1 by FGF-2 involves activity of EGR-1 and sensitizes neuroblastoma cells to cell death. Journal of Cellular Physiology 226 1763-1770. (https://doi.org/10.1002/jcp.22505)

Pepper MS 2001 Role of the matrix metalloproteinase and plasminogen activator-plasmin systems in angiogenesis. Arteriosclerosis, Thrombosis and Vascular Biology 21 1104-1117. (https://doi.org/10.1161/hq0701.093685)

Petrik JJ, Gentry PA, Feige JJ \& LaMarre J 2002 Expression and localization of thrombospondin-1 and -2 and their cell-surface receptor, CD36, during rat follicular development and formation of the corpus luteum. Biology of Reproduction 67 1522-1531. (https://doi.org/10.1095/ biolreprod.102.007153)

Ren B, Yee KO, Lawler J \& Khosravi-Far R 2006 Regulation of tumor angiogenesis by thrombospondin-1. Biochimica et Biophysica Acta (BBA): Reviews on Cancer 1765 178-188. (https://doi.org/10.1016/j. bbcan.2005.11.002)

Resovi A, Pinessi D, Chiorino G \& Taraboletti G 2014 Current understanding of the thrombospondin-1 interactome. Matrix Biology 37 83-91. (https:// doi.org/10.1016/j.matbio.2014.01.012)

Ribeiro SM, Poczatek M, Schultz-Cherry S, Villain M \& Murphy-Ullrich JE 1999 The activation sequence of thrombospondin-1 interacts with the latency-associated peptide to regulate activation of latent transforming growth factor-beta. Journal of Biological Chemistry 274 13586-13593. (https://doi.org/10.1074/jbc.274.19.13586)

Robertson IB \& Rifkin DB 2013 Unchaining the beast; insights from structural and evolutionary studies on TGFbeta secretion, sequestration, and activation. Cytokine and Growth Factor Reviews 24 355-372. (https://doi.org/10.1016/j.cytogfr.2013.06.003)

Robinson R, Nicklin L, Hammond A, Schams D, Hunter M \& Mann G 2007 Fibroblast growth factor 2 is more dynamic than vascular endothelial growth factor A during the follicle-luteal transition in the cow. Biology of Reproduction 77 28-36. (https://doi.org/10.1095/biolreprod.106.055434)

Robinson CL, Zhang L, Schutz LF, Totty ML \& Spicer LJ 2018 MicroRNA 221 expression in theca and granulosa cells: hormonal regulation and function. Journal of Animal Science 96 641-652. (https://doi. org/10.1093/jas/skx069)

Rodriguez-Manzaneque JC, Lane TF, Ortega MA, Hynes RO, Lawler J \& Iruela-Arispe ML 2001 Thrombospondin-1 suppresses spontaneous tumor growth and inhibits activation of matrix metalloproteinase-9 and mobilization of vascular endothelial growth factor. PNAS 98 12485-12490. (https://doi.org/10.1073/pnas.171460498)

Romero JJ, Antoniazzi AQ, Smirnova NP, Webb BT, Yu F, Davis JS \& Hansen TR 2013 Pregnancy-associated genes contribute to antiluteolytic mechanisms in ovine corpus luteum. Physiological Genomics 45 1095-1108. (https://doi.org/10.1152/physiolgenomics.00082.2013)

Romero J, Antoniazzi AQ, Nett TM, Ashley RL, Webb BT, Smirnova NP, Bott RC, Bruemmer JE, Bazer FW, Anthony RV et al. 2015 Temporal release, paracrine and endocrine actions of ovine conceptus-derived interferon-tau during early pregnancy. Biology of Reproduction 93146. (https://doi.org/10.1095/biolreprod.115.132860)

Rueda BR, Hendry IR, Tilly JL \& Hamernik DL 1999 Accumulation of caspase-3 messenger ribonucleic acid and induction of caspase activity in the ovine corpus luteum following prostaglandin F2 $\alpha$ treatment in vivo. Biology of Reproduction 60 1087-1092. (https://doi.org/10.1095/ biolreprod60.5.1087) 
Sanchez-Capelo A 2005 Dual role for TGF-beta1 in apoptosis. Cytokine and Growth Factor Reviews 16 15-34. (https://doi.org/10.1016/j. cytogfr.2004.11.002)

Santiago FS, Lowe HC, Bobryshev YV \& Khachigian LM 2001 Induction of the transcriptional repressor yin yang- 1 by vascular cell injury autocrine/ paracrine role of endogenous fibroblast growth factor-2. Journal of Biological Chemistry 276 41143-41149. (https://doi.org/10.1074/jbc.M104913200)

Schams D \& Berisha B 2004 Regulation of corpus luteum function in cattle - an overview. Reproduction in Domestic Animals 39 241-251. (https:// doi.org/10.1111/j.1439-0531.2004.00509.x)

Shirasuna K, Nitta A, Sineenard J, Shimizu T, Bollwein H \& Miyamoto A 2012 Vascular and immune regulation of corpus luteum development, maintenance, and regression in the cow. Domestic Animal Endocrinology 43 198-211. (https://doi.org/10.1016/j.domaniend.2012.03.007)

Simantov R, Febbraio M \& Silverstein R 2005 The antiangiogenic effect of thrombospondin-2 is mediated by CD36 and modulated by histidinerich glycoprotein. Matrix Biology 24 27-34. (https://doi.org/10.1016/j. matbio.2004.11.005)

Smith MF, Ricke WA, Bakke LJ, Dow MP \& Smith GW 2002 Ovarian tissue remodeling: role of matrix metalloproteinases and their inhibitors. Molecular and Cellular Endocrinology 191 45-56. (https://doi. org/10.1016/S0303-7207(02)00054-0)

Sottile J, Selegue J \& Mosher DF 1991 Synthesis of truncated aminoterminal trimers of thrombospondin. Biochemistry 30 6556-6562. (https://doi.org/10.1021/bi00240a028)

Staniszewska I, Zaveri S, Del Valle L, Oliva I, Rothman VL, Croul SE, Roberts DD, Mosher DF, Tuszynski GP \& Marcinkiewicz C 2007 Interaction of alpha9beta1 integrin with thrombospondin-1 promotes angiogenesis. Circulation Research 100 1308-1316. (https://doi. org/10.1161/01.RES.0000266662.98355.66)

Sun C, Feng SB, Cao ZW, Bei JJ, Chen Q, Zhao WB, Xu XJ, Zhou Z, Yu ZP \& Hu HY 2017 Up-regulated expression of matrix metalloproteinases in endothelial cells mediates platelet microvesicle-induced angiogenesis. Cellular Physiology and Biochemistry 41 2319-2332. (https://doi. org/10.1159/000475651)

Sweetwyne MT \& Murphy-Ullrich JE 2012 Thrombospondin 1 in tissue repair and fibrosis: TGF-beta-dependent and independent mechanisms. Matrix Biology 31 178-186. (https://doi.org/10.1016/j.matbio.2012.01.006)

Tan K, Duquette M, Liu JH, Zhang R, Joachimiak A, Wang JH \& Lawler J 2006 The structures of the thrombospondin-1 N-terminal domain and its complex with a synthetic pentameric heparin. Structure 14 33-42. (https://doi.org/10.1016/j.str.2005.09.017)

Taraboletti G, Morbidelli L, Donnini S, Parenti A, Granger HJ, Giavazzi R \& Ziche M 2000 The heparin binding 25 kDa fragment of thrombospondin-1 promotes angiogenesis and modulates gelatinase and TIMP-2 production in endothelial cells. FASEB Journal 14 1674-1676. (https://doi.org/10.1096/fj.99-0931fje)

Thomas FH, Wilson H, Silvestri A \& Fraser HM 2008 Thrombospondin-1 expression is increased during follicular atresia in the primate ovary. Endocrinology 149 185-192. (https://doi.org/10.1210/en.2007-0835)

Thornton TM \& Rincon M 2009 Non-classical p38 map kinase functions: cell cycle checkpoints and survival. International Journal of Biological Sciences 5 44-51. (https://doi.org/10.7150/ijbs.5.44)

Tsang M \& Dawid IB 2004 Promotion and attenuation of FGF signaling through the Ras-MAPK pathway. Science Signaling 2004 pe17. (https:// doi.org/10.1126/stke.2282004pe17)
Vincenti S, Brillante N, Lanza V, Bozzoni I, Presutti C, Chiani F, Etna MP \& Negri R 2011 HUVEC respond to radiation by inducing the expression of pro-angiogenic microRNAs. Radiation Research 175 535-546. (https:// doi.org/10.1667/RR2200.1)

Vogel T, Guo NH, Krutzsch HC, Blake DA, Hartman J, Mendelovitz S, Panet A \& Roberts DD 1993 Modulation of endothelial cell proliferation, adhesion, and motility by recombinant heparin-binding domain and synthetic peptides from the type I repeats of thrombospondin. Journal of Cellular Biochemistry 53 74-84. (https://doi.org/10.1002/jcb.240530109)

Volpert OV, Pili R, Sikder HA, Nelius T, Zaichuk T, Morris C, Shiflett CB, Devlin MK, Conant K \& Alani RM 2002 Id1 regulates angiogenesis through transcriptional repression of thrombospondin-1. Cancer Cell 2 473-483. (https://doi.org/10.1016/S1535-6108(02)00209-X)

Wang S, Wu Z, Sorenson CM, Lawler J \& Sheibani N 2003 Thrombospondin1-deficient mice exhibit increased vascular density during retinal vascular development and are less sensitive to hyperoxia-mediated vessel obliteration. Developmental Dynamics 228 630-642. (https://doi. org/10.1002/dvdy.10412)

Xing C, Lee S, Kim WJ, Jin G, Yang YG, Ji X, Wang X \& Lo EH 2009 Role of oxidative stress and caspase 3 in CD47-mediated neuronal cell death. Journal of Neurochemistry 108 430-436. (https://doi.org/10.1111/ j.1471-4159.2008.05777.x)

Yadav VK, Lakshmi G \& Medhamurthy R 2005 Prostaglandin F2alphamediated activation of apoptotic signaling cascades in the corpus luteum during apoptosis: involvement of caspase-activated DNase. Journal of Biological Chemistry 280 10357-10367. (https://doi.org/10.1074/jbc. M409596200)

Yamashita H, Kamada D, Shirasuna K, Matsui M, Shimizu T, Kida K, Berisha B, Schams D \& Miyamoto A 2008 Effect of local neutralization of basic fibroblast growth factor or vascular endothelial growth factor by a specific antibody on the development of the corpus luteum in the cow. Molecular Reproduction and Development 75 1449-1456. (https://doi. org/10.1002/mrd.20878)

Yanagishita M 1994 Proteoglycans and hyaluronan in female reproductive organs. Exs 70 179-190.

Zabuawala T, Taffany DA, Sharma SM, Merchant A, Adair B, Srinivasan R, Rosol TJ, Fernandez S, Huang K \& Leone G 2010 An ets2-driven transcriptional program in tumor-associated macrophages promotes tumor metastasis. Cancer Research 70 1323-1333. (https://doi. org/10.1158/0008-5472.CAN-09-1474)

Zalman Y, Klipper E, Farberov S, Mondal M, Wee G, Folger JK, Smith GW \& Meidan R 2012 Regulation of angiogenesis-related prostaglandin f2alpha-induced genes in the bovine corpus luteum. Biology of Reproduction 86 92. (https://doi.org/10.1095/biolreprod.111.095067)

Zhang YE 2009 Non-Smad pathways in TGF-beta signaling. Cell Research 19 128-139. (https://doi.org/10.1038/cr.2008.328)

Received 7 October 2018

First decision 1 November 2018

Revised manuscript received 5 December 2018

Accepted 17 December 2018 